\title{
JUURNAL.RU
}

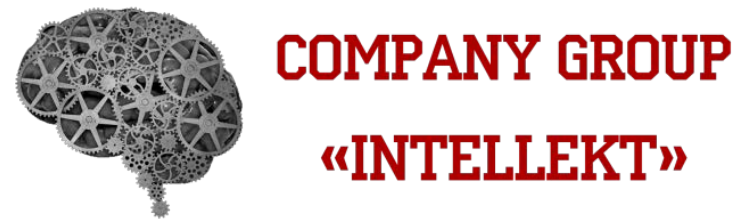

Никитина Н.С., Никитин С.С. МБУЗ городская больница № 2 Новочеркасск, Россия

doi: 10.18411/lj2016-6-3-04

\section{Стабилизация вестибулярной компенсации при болезни Меньера}

Болезнь Меньера (БМ) - заболевание, известное более 100 лет, попрежнему остается малопонятным и нередко представляет трудности для диагностики [1]. Несмотря на обилие предложенных способов диагностики с использованием дорогостоящих технических средств, ни один из них не выявил патогномоничных признаков БМ [2] и диагностика этого заболевания проводится, в основном, клинически.

Морфологическим субстратом БМ является эндолимфатический гидропс , который объясняют сосудистыми, инфекционными, гормональными, аутоиммунными, травматическими и метаболическими причинами $[3,4,5]$, однако ни одна из них не получила достаточных доказательств [6].

Болезнь Меньера характеризуется периодически возникающими приступами системного головокружения, наличием шума в ухе и прогрессирующим снижением слуха. Степень выраженности слуховых и вестибулярных нарушений с годами приобретает различную направленность: если вестибулярные нарушения постепенно ослабевают, то слуховые расстройства часто заканчиваются развитием стойкой тугоухости и даже глухоты. Для успешного лечения слуховых расстройств при болезни Меньера необходим точный диагноз, поскольку подобное сочетание слуховых и вестибулярных нарушения встречается и при другой патологии внутреннего уха $[7,8,9,10]$. 
В комплексе средств медикаментозного лечения кохлеовестибулярных нарушений важное место отводится вазоактивным препаратам. Эти препараты должны отвечать ряду требований, главное из которых - воздействие на церебральную гемодинамику, что обеспечивает улучшение кровообращения области вестибулярных ядер. Однако для лечения болезни Меньера необходимо улучшение кровоснабжения как ядерного, так и периферического отделов слухового и вестибулярного анализаторов.

К сожалению, далеко не все вазоактивные препараты центрального действия способны оптимизировать кровообращение внутреннего уха. Одним из немногих средств, которым присуще это свойство, является бетагистина дигидрохлорид. Фармакологические исследования на животных выявили увеличение кохлеарного кровотока при введении бетагистина дигидрохлорида. Этот эффект зависит от дозы препарата и в большей степени проявляется в сосудистой сети улитки, чем в системном сосудистом русле.

Механизм действия бетагистина дигидрохлорида (бетасерка) включает действие на кохлеарный кровоток, на центральные и рецепторные отделы вестибулярного анализатора.

Действие бетагистина реализуется, в основном, через гистаминовые рецепторы, значительное количество которых обнаружено и в мелких артериях внутреннего уха. Последний факт объясняет эффект улучшения кровоснабжения внутреннего уха под влиянием бетагистина дигидрохлорида.

Целью нашего исследования было изучение влияния бетасерка (бетагистина дигидрохлорида) на вестибулярную функцию у больных с болезнью Меньера.

Бетасерк был использован для курсового лечения 14 больных в возрасте от 28 до 44 лет, 11 женщин и 3 мужчин. Продолжительность заболевания составляла в среднем 2,7 года. Все больные жаловались на одностороннюю флюктуирующую тугоухость и шум в ухе, усиливающийся накануне и во время 
приступа головокружения. Типичные приступы системного головокружения наблюдались от 2 до 8 раз в год.

Больным проведено общеклиническое и отоневрологическое исследование, произведена тональная пороговая аудиометрия и триплексное сканирование сосудов шеи.

По данным аудиометрии у всех больных отмечено повышение порогов слуха по воздушной проводимости в зоне речевых частот от 20 до 50 дБ. Преобладающим типом кривых был вогнутый, с наличием костно-воздушного интервала от 10 до 30 дБ на низких частотах.

Больным проведено лечение бетасерком в дозах, рекомендуемых фирмой производителем: по 24 мг 2 раза в день. Продолжительность лечения составила 3 месяца. Результаты лечения оценивали по окончанию приема препарата и по истечению срока от 8 до16 месяцев.

Субъективное улучшение отмечено не ранее чем через 3 недели от начала приема препарата. Стабилизация вестибулярной функции достигнута у всех больных - повторения приступов головокружения в указанные сроки наблюдения не отмечено.

Аудиогические нарушения регрессировали у 9 больных, при аудиометрическом исследовании которых выявлено понижение порогов слуха по воздушной проводимости на 15 - 30 дБ по сравнению с исходными значениями, по костной - на 10 - 20 дБ. 3 больных отметили ослабление или исчезновения субъективного ушного шума.

Таким образом, у большинства больных, принимавших бетасерк, зарегистрирована стабилизация вестибулярной и слуховой функции. Важным прогностическим моментом является развитие у этих больных стойкой вестибулярной компенсации, поскольку на состояние слухового рельефа оказывает влияние частота и выраженность приступов головокружения: с нарастанием их частоты и продолжительности нарушения слуха прогрессируют. 
Наши наблюдения свидетельствуют о высокой эффективности бетасерка в лечении болезни Меньера, что согласуется с данными других авторов. В результате курсового применения препарата не только достигнута вестибулярная ремиссия, но и отмечено стойкое улучшение слуховой функции у $64 \%$ больных. 


\section{Литература:}

1. Бойко Н.В. Головокружение в практике врача-терапевта. Лечащий врач. 2010. № 4. C. 86.

2. Бойко Н.В. Головокружение в практике врача. Журнал неврологии и психиатрии им С.С. Корсакова. 2005. Т. 105. № 1. С. 74-77.

3. Бойко Н.В., Колмакова Т.С. Содержание гормонов в крови при болезни Меньера. Рос. оторинолар. 2014. Т. 72. № 5. С. 15-19.

4. Boyko N.V., Kolmakova T.S. Blood hormones level in patients with Menieres disease. Мат III Междунар науч-практ конф «Современные проблемы развития фундаментальных и прикладных наук» Praha, Czech Republic. 2016. T. 1. C. 16-19.

5. Колмакова Т.С., Смирнова О.Б., Белякова Е.И. Антиоксидантные свойства ликвора при дегенеративных заболеваниях мозга. Нейрохимия. 2010. T. 27. № 1. С. 47-52.

6. Хананашвили Я.А., Бойко Н.В., Волков А.Г., Харахашян А.А. Исторические основы современной вестибулологии и отоневрологии (к 100-летию присуждения Нобелевской премии). Журнал фундаментальной медицины и биологии. 2014. № 2. С. 9-16.

7. Бойко Н.В. Синдром расширенного водопровода преддверия. Российская оториноларингология. 2015. Т. 78. № 5. С.79-82

8. Бойко Н.В., Колесников В.Н. Фистула лабиринта у больных хроническим гнойным средним отитом. Российская оториноларингология. 2012. № 4. C. $127-132$.

9. Колесников В.Н., Бойко Н.В. Хирургическое лечение хронического гнойного среднего отита, осложненного фистулой лабиринта. Российская оториноларингология. 2012. Т. 61. № 6. С. 75-80.

10. Boyko N.V., Kolesnikov V.N. Surgical management of labyrinthine fistula in chronic otitis media. Сорвеменные проблемы развития фундаментальных и прикладных наук. Мат. III междунар науч-практ конф. 2016. С. 19-23. 